\title{
A COMPARATIVE STUDY: AUSTRALIAN ENGLISH AND INDONESIAN COMPLIMENTING BEHAVIOURS
}

\author{
Atik Yuliyani \\ Syarif Hidayatullah State Islamic University of Jakarta, Indonesia \\ (atik@uinjkt.ac.id)
}

Received: $09^{\text {th }}$ April 2016; Revised: $05^{\text {th }}$ May 2016; Accepted: $25^{\text {th }}$ June 2016

\section{ABSTRACT}

The present study investigates the similarities and differences between Australian English and Indonesian speakers on paying compliments. A total of 50 university-student informants participated in the study: 25 Indonesian native speakers and 25 Australian English native speakers. The data were collected through a written Discourse Completion Task (DCT) which consists of eight situational settings. The results showed some similarities and differences between Australian English and Indonesian speakers on paying compliment. The similarities included the fact that ability was the most frequently preferred topic for both Indonesians and Australians, both Indonesians and Australians were more likely to give explicit verbal compliment, and compliments occurred mostly from males to females. The differences were: firstly, Australians used implicit compliment as their second preference, while Indonesians used 'no-response' type. Secondly, Australian females gave more explicit verbal compliment than the males did, whereas Indonesian females and males gave almost equal amount of explicit verbal compliment. Thirdly, the second most frequent positive semantic carriers were adverbs in Indonesian, but verbs in Australian English.

Key Words: compliment behaviour; compliment strategies; compliment focus

\section{ABSTRAK}

Penelitian ini menyelidiki persamaan dan perbedaan antara Australia dan Indonesia dalam memberikan pujian. Sebanyak lima puluh mahasiswa yang terdiri dari 25 mahasiswa Australia dan 25 mahasiswa Indonesia terlibat dalam penelitian ini sebagai informan. Data dikumpulkan melalui instrument tertulis (DCT) yang terdiri dari delapan seting. Hasil penelitian menunjukkan beberapa persamaan dan perbedaan antara Australia dan Indonesia dalam memberikan pujian. Persamaannya meliputi kemampuan (ability) menjadi topik yang paling disukai oleh keduanya, baik Indonesia dan Australia lebih senang memberikan pujian lisan secara eksplisit, dan pujian terjadi sebagian besar dari laki-laki ke perempuan. Adapun perbedaannya antara lain: pertama, Australia menggunakan pujian implicit sebagai preferensi kedua sementara Indonesia menggunakan tipe 'no response'. Kedua, wanita Australia memberi pujian lisan secara eksplisit lebih daripada laki-laki lakukan, sedangkan wanita dan pria Indonesia memberi jumlah yang hampir sama dari pujian lisan eksplisit. Ketiga, kata keterangan (adverbs) menjadi ungkapan semantik positif kedua yang digunakan Indonesia, sedangkan Australia menggunakan kata kerja (verbs) sebagai ungkapan semantik positif kedua.

Kata Kunci: perilaku pujian; strategi pujian; fokus pujian

How to Cite: Yuliani, A. (2016). A Comparative Study: Australian English and Indonesian Complimenting Behaviours. IJEE (Indonesian Journal of English Education), 3(1), 15-28. doi:10.15408/ijee.v3i1.3940

Permalink/DOI: http://dx.doi.org/10.15408/ijee.v3i1.3940 


\section{INTRODUCTION}

Rules of speaking, or speech act patterns, are different from culture to culture (Cohen, cited in McKay \& Hornberger, 2006). They are different in the way that they are realized, their distribution, and their frequency of occurrence as well as the function they serve. These facts make it difficult for learners to realize some speech acts in general target language in terms of both communicative effectiveness and social appropriateness. In addition, these differences often lead to misunderstanding between speakers. Hence, to be able to interpret what is said, non-native speakers of English need to understand the cultural values which underlie the pattern of speech. As Holmes (2008) stated learning another language usually involves a great deal more than learning the literal meaning of the words, how to put them together, and how to pronounce them. We need to know what it means in the cultural context in which it is normally used. This involves some understanding of the cultural and social norms of its users.

A compliment is one form of speech acts which involves such cultural issues. Complimenting varies across cultures. Holmes (1988, p. 485) defined compliment as "a speech act which explicitly or implicitly attributes credit to someone other than the speaker, usually the person addressed, for some 'good' (possession, characteristic, skill, etc.) which is positively valued by the speaker and the hearer". Thus, paying a compliment and responding to it can be a challenge for non-native speakers whose social values and norms are different from those in the target language culture. It is evident from previous studies of compliments

This small speech event is actually far more complicated and revealing than it appears, in terms of the relation between language, society, and culture (Wolfson, 1981; Holmes \& Brown, 1987; Ye, 1995; Farghal, 2006). In particular, what counts as a compliment may differ very much from one society to another. In addition, the way it is realized, its distribution, its frequency of occurrence, and the functions it serve may also differ cross-culturally. In fact, these differences often lead to misunderstanding between speakers, especially from different cultural background.

In order to make a comparison between the ways compliments function in English and in other languages, a study of how native and non-native speakers of English paying a compliment would benefit those in the realm of English pedagogy and cross- 
cultural communication. This study investigates similarities and differences between Australian English and Indonesian speakers on paying compliments. It is hoped that it can provide some useful information from a cultural perspective as well as information for ESL/EFL teachers, especially Indonesian teachers.

Liu (1997, cited in Al Falasi, 2007, p. 31) later defined compliment as "an utterance containing a positive evaluation by the speaker to the addressee". Moreover, Hobbs (2003, p. 249) defined "a compliment is a speech act which explicitly or implicitly bestows credit upon the addressee for some possession, skill, characteristic, or the like, that is positively evaluated by the speaker and addressee". From these definitions, it can be concluded that to be heard as a compliment an utterance must refer to something which is positively valued by the participants and attributed to the addressee.

Compliments are viewed within the framework of politeness theory. On the one hand, a compliment may be regarded as a positive speech act. On the other hand, it may also be regarded as a face-threatening act (FTA). Brown and Levinson (1987, p. 247) point out that compliments may be significant FTAs in societies where envy is very strong and where witchcraft exists as a sanction. Holmes (1988, p. 448) remarks, "compliments can be regarded as face threatening to the extent that they imply the complimenter envies the addressee in some way or would like to have something belonging to the addressee". Similarly, Yu (2003, p. 1687) argues that "due to the fact that compliments can be threatening to the addressee's face as they, like criticisms, are an act of judgment on another person, many people feel uneasy, defensive, or even cynical with regard to the compliments they receive, and thus may have trouble responding to such compliments appropriately". Thus, from these various perceptions, it can be concluded that whether a compliment is a positive or negative speech act depends upon a number of factors, including context, cultural protocols and individual interpretation.

Systematic studies and closer investigation on the linguistic form of 686 examples of American English native speakers' compliments discovered that regularities exist and that compliments are in fact formulas (Manes and Wolfson, 1981). It is obvious that since compliments are expressions of positive evaluation, each must include at least one term which carries positive semantic load. Manes and Wolfson (1981) found in their study that adjectives and verbs were the two 
most commonly type used in compliments as positive semantic loads. They found that approximately $80 \%$ of American English compliments fall into the three syntactic patterns:

1. NP (Noun Phrase be/look (Intensifier) ADJ (Adjective)

e.g. You look (really) great

2. I (Intensifier) like/love NP e.g. I (really) like your dress

3. Pro be (Intensifier) (a) ADJ NP e.g. That's (really) nice shoes

In addition, two-thirds of English compliments use the adjectives 'nice, good, beautiful, pretty, great'. A similar result was also found in a study of New Zealand English compliments by Holmes and Brown (1987).

Regarding the compliment topic, Manes and Wolfson (1981) found that English compliments fall into two major categories with respect to topic: those having to do with appearance (e.g., apparel, hair-do, homes, furniture, automobiles, and other possessions) and those which comment on ability. However, studies in other speech communities have shown that complimentable values vary across cultures. In the Japanese society, for example, one's appearance, which is greatly valued in English speaking communities, is not the most frequently mentioned topic (Ide, 1998). The most frequently referred topic is that of one's ability and achievement. In Korean speech community, Baek (1998) reported that compliments on a person's personality occur more frequently in Korean than in English. Therefore, it is obvious to say that with regard to compliment topic, it is closely related to a variety of cultural norms and values of a given society.

Comparative studies between American English and other languages have been increasingly conducted. For instance, Chinese (Ye, 1995), Japanese (Ide, 1998), Korean (Baek, 1998), and Arabic (Farghal, 2006). The results of these studies show that not all the patterns appear in American English might appear in the other languages or cultures context. There were some patterns which were more preferred to appear than others. In Chinese, for example, verbs, which are frequently used in different varieties of English compliments, turn out to be rarely used. However, adjectives become the most frequent positive semantic carriers that are used in Chinese (Ye, 1995). These variations on paying a compliment among different languages can lead this study in investigating the similarities and differences between Australian English and Indonesian on paying compliments.

In terms of compliments as a gender-preferential strategy, there are 
some similarities as well as differences between American English speakers and other English varieties, such as New Zealand and Australian. Holmes' study $(1988 ; 1993)$ on New Zealand English speakers found that $23.1 \%$ of compliments occur from males to females in comparison to $16.5 \%$ from females to males. This is in line with Parisi and Wogan's (2006) study on American English which found 60.53\% compliments occur from males to females in comparison to $29.27 \%$ from females to males. Furthermore, Holmes' study $(1988 ; 1993)$ shows that the most popular compliment topic is that of 'appearance' with female-female interactions complimenting on appearance $61 \%$ of the time, malefemale $47 \%$, female-male $40 \%$ and male-male, a surprising $36 \%$. The latter finding shows male-male interactions complimenting on appearance is the difference between American English and other English varieties, such as New Zealand. Such a high percentage amongst males would generally not occur amongst American men. In fact, such differences can be influenced by some factors, such as a relationship between speakers. These findings can be used for this study as a reference for the Australian response to compliments as well as a comparison to Indonesian response to compliments.
With regard to data collection, researchers on complimenting behaviours used different methods. Ethnographic method, interview, role plays and discourse completion tasks (DCT) have been used for data collection. DCT is one of the commonly used methods. As Mackay and Gass (2008) argue, DCTs can provide a 'sound template of stereotypically perceived requirements for socially appropriate speech act in the groups studied'. It also enables the researcher to obtain sufficient data in a relatively short period of time. Therefore, it becomes an obvious choice for this study to follow as a data gathering method.

Since compliment behaviour varies from culture to culture, and there is little or no previous study on Indonesian compliment behaviour, the present study is conducted to add to the research into this speech act. This study differs from previous studies in that it conducts a comparative study of complimenting behaviours using data from Indonesian and Australian English speakers. This study seeks to investigate the similarities and differences between Australian English and Indonesian speakers on paying compliment in terms of compliment strategies, compliment formulas, and compliment focus. 
Table 1. General features of the eight DCT situations

\begin{tabular}{lll}
\hline & Compliment & \\
\hline Situation & Gender of complimentee & Compliment topic \\
S1- blouse & Female & Appearance \\
S2- cook & Female & Ability \\
S3- sneakers & Male & Appearance \\
S4- playing guitar & Male & Ability \\
& Compliment Response & \\
Situation & Gender of complimentor & Compliment topic \\
S5- clothes & Male & Appearance \\
S6- basketball & Male & Ability \\
S7- hair & Female & Appearance \\
\hline S8- singing & Female & Ability \\
\hline
\end{tabular}

The following are the description of the eight DCT situations:

Compliment

S-1 Blouse: You meet your friend Suzanne in a mall and notice that she is wearing a new blouse today.

S-2 Cook: You are at a farewell party and eating spaghetti. You notice that your friend Jennifer made the spaghetti and she is good at making it.

S-3 Sneakers: You are playing tennis with your friend David. You notice that he is wearing a new pair of tennis shoes today.

S-4 Playing guitar: You are having a gathering with your friends in a park. You notice that one of your friends, Scott is good at playing guitar.

Compliment responses

S-5 Clothes: You wear new dress to campus today. Then you meet your friend Mike there. He says "Hi, You look great today!"

S-6 Basketball: You and your friend George are playing a basketball together. Then, he says: "You're a good basketball player".

S-7 Hair: You just had your hair done. You meet your neighbour Sylvia on your way home. She says: "You look great with your hair done".

S-8 Singing: You perform a song in your friend's birthday and one of your friends, Tania likes your performance very much. She then says: "You're a good singer, your voice is so beautiful".

\section{METHOD}

\section{Participants}

A total of 50 participants contributed to this study: 25 Indonesian native speakers and 25 Australian English native speakers. There were 12 male and 13 female participants in each group. All participants were university students, aged from 20 to 40 . The Indonesian native speakers were university students in various universities in Jakarta, Indonesia, who had learned English for at least six years. None of them had been to a foreign country. The Australian English native speakers were university students in Canberra.

\section{Data Collection Instrument}

The data were obtained via a Discourse Completion Task (DCT). Two language versions of eight situational settings with the same content on the DCT, Indonesian and English, were distributed. The DCT employed was a replica as that used by Ye (1995) with some modification. Options for zero realization were also given in the DCT format by providing a choice of "You do not say anything" or "You do not respond". In the DCT, eight situational settings relating to two different topics were employed: appearance and ability. Four situations for compliments (S1-S4) and another four situation for compliment responses (S5-S8). The 
general features of the eight DCT situations are displayed in Table 1.

It is worth mentioning that questions on the DCT in this study involve equal social status and close relationships between the interlocutors.

Due to the limitation of time and the large amount of the data to be analysed, it was only the first four situations (S1-S4) analysed in this study.

\section{Data Analysis}

The data were analysed by adapting Ye's data analytical procedure in which all the data were coded and percentages were calculated for the major semantic formula of compliments, including compliment strategies and compliment formulas. The compliment strategies were categorized into four, including: No Response, Explicit Compliment, Implicit Compliment, and Non-Compliment.

According to Ye (1995), the technical term No response refers to the zero realization where the respondents chose "You would not say anything". While Non-compliment is where the respondents did give verbal utterances to the given situations but those utterances can hardly be categorized as compliments. For example, "Are you trying to put my game off with the glame!" or "Hope you don't get blisters from your new shoes. I'm going to run you around today".

Implicit Compliment refers to those compliments which are not explicitly directed to the complimentee's appearance or ability. For instance, "It must be great to be able to play guitar. I wish I could". Explicit Compliment refers to a direct positive comment in which the form contains at least one positive semantic carrier. Such as, "That is a nice blouse!" or "Wow Suzanne I love your blouse! It's such a nice colour!"

Compliment formulas were analysed by positive semantic carriers and compliment focus (Ye, 1995, p. 223). Positive semantic carriers were grouped into Adjectives, Adverbs, and Verbs. For example, "You look beautiful" or "That's a nice dress". The positive semantic carriers are adjectives. In a sentence like "You play the guitar well", here the positive semantic carriers is an adverb. The use of verb as positive semantic carriers in compliment, for instance, "I like your new shoes".

Compliment focus refers to the major focus of the compliment utterance. It can be categorized into Object/Action and Agent. Object/Action refers to those utterances which focus either on objects or actions of the complimentee. On the other hand, 
Agent refers to the complimentee him/herself.

\section{FINDINGS}

Based on the research questions, the results were presented into three sections: (1) compliment strategies, (2) compliment formulas, and compliment focus.

\section{Compliment strategies}

The compliment strategies were categorized into four, including: No Response, Explicit Compliment, Implicit Compliment, and Non-Compliment. These four types of compliment responses were analysed by their overall distributions, contextual factors (topics), and gender-specific distributions.

A total of 200 responses were collected, 100 in Indonesian and 100 in Australian English, from the compliment situations (situations S 1S4). The distribution of the responses is displayed in Table 2.

As indicated in Table 2, Indonesians gave more explicit verbal compliment than Australians did. Indonesians gave a total of $69 \%$ of explicit verbal compliment while Australians gave only $61 \%$ of explicit verbal compliment. Table 2 also shows that Indonesians used 'No Response' as their second preference of compliment type. On the other hand, Australians used Implicit Compliment as their second preference.

Table 2. Overall distribution of compliment types (\%)

\begin{tabular}{|c|c|c|}
\hline $\begin{array}{l}\text { Types } \\
\text { compliment }\end{array}$ & Indonesian & Australian \\
\hline No Response & 13 & 14 \\
\hline Explicit & 69 & 61 \\
\hline Compliment & & \\
\hline $\begin{array}{l}\text { Implicit } \\
\text { Compliment }\end{array}$ & 8 & 19 \\
\hline Non-Compliment & 10 & 6 \\
\hline Total & 100 & 100 \\
\hline
\end{tabular}

Compliment strategies are further examined by the two compliment topics: appearance and ability, and the results are shown in Table 3. Table 3 shows that the most frequently preferred topic for both Indonesians and Australians is that of one's ability. For the Indonesians, 38\% of compliments were given to the topic of ability in comparison to $31 \%$ of appearance. The Australians gave 36\% of the compliment on ability in comparison to $24 \%$ on appearance.

Results show that both Indonesian and Australian males and females had the same preference concerning Explicit Compliment. However, there was a difference in the amount of percentage between males and females. Indonesian males and females gave almost equal amount of 
explicit verbal compliment. By contrast, The percentage of distribution of Australian females gave more explicit compliment types by gender of verbal compliment than the males did. complimentor is presented in Table 4 .

Table 3. Distribution of compliment types by compliment topic (\%)

\begin{tabular}{lllll}
\hline Types of compliment & Appearance & & Ability & \\
\cline { 2 - 5 } & Indonesian & Australian & Indonesian & Australian \\
No response & 9 & 12 & 5 & 2 \\
Explicit compliment & 31 & 24 & 38 & 36 \\
Implicit compliment & 2 & 9 & 6 & 10 \\
\hline Non-compliment & 9 & 6 & 1 & 0 \\
\hline
\end{tabular}

Table 4. Distribution of compliment types by gender (\%)

\begin{tabular}{lllll}
\hline Types of compliment & Male & \multicolumn{3}{l}{ Female } \\
\cline { 2 - 5 } & Indonesian & Australian & Indonesian & Australian \\
No response & 4 & 9 & 9 & $\mathbf{5}$ \\
Explicit compliment & 35 & 24 & 34 & $\mathbf{3 7}$ \\
Implicit compliment & 4 & 14 & 4 & $\mathbf{5}$ \\
\hline Non-compliment & $\mathbf{5}$ & $\mathbf{5}$ & $\mathbf{5}$ & $\mathbf{1}$ \\
\hline
\end{tabular}

Table 5. Distribution of compliment types by interaction between genders

\begin{tabular}{lllllllll}
\hline Types of compliment & M-f & & F-f & & M-m & \multicolumn{3}{l}{ F-m } \\
\cline { 2 - 9 } & Indo & Aus & Indo & Aus & Indo & Aus & Indo & Aus \\
No response & 1 & 7 & 4 & 0 & 3 & 3 & 5 & 4 \\
Explicit compliment & 21 & 17 & 20 & 22 & 14 & 7 & 14 & 15 \\
Implicit compliment & 0 & 5 & 1 & 0 & 3 & 9 & 4 & 5 \\
\hline Non-compliment & 4 & 0 & 3 & 1 & 3 & 5 & 0 & 0 \\
\hline
\end{tabular}

Table 6. Overall distribution of positive semantic carriers (\%)

\begin{tabular}{lll}
\hline Types of positive semantic carriers & Indonesian & Australian \\
\hline Adjective & 88.4 & 86.9 \\
Adverb & 11.6 & 3.3 \\
\hline Verb & 0 & 9.8 \\
\hline
\end{tabular}

Table 7. Distribution of compliment focus (\%)

\begin{tabular}{lll}
\hline Compliment focus & Indonesian & Australian \\
\hline Agent & 20.3 & 13.1 \\
\hline Object/Action & 79.7 & 86.9 \\
\hline
\end{tabular}


When the gender-specific distributions were further examined in terms of the interaction between the gender of complimentor and complimentee (see Table 5), the results showed similarity between Indonesians and Australians. For both Indonesians and Australians, more compliments occurred from males to females than the vise versa. In addition, females compliment other females more often than males. As indicated in Table 5, for the Indonesians, $21 \%$ of compliments occurred from males to females in comparison to $14 \%$ from females to males. And $20 \%$ of compliments occurred from female to female in comparison to $14 \%$ from male to male. For the Australians, $17 \%$ of compliments occurred from males to females in comparison to $15 \%$ from females to males. And $22 \%$ of compliments occurred from female to female in comparison to $7 \%$ from male to male.

\section{Compliment formulas}

Compliment formulas were analysed by positive semantic carriers and compliment focus. In analysing compliment formulas, it is only the utterances in the category of Explicit Compliment were examined. Explicit Compliment entails three types of positive semantic carriers, Adjectives, Verbs, and Adverb. The results revealed that Adjectives were the most frequent positive semantic carriers in both Indonesians and Australians. The percentage of overall distribution of positive semantic carriers is presented in Table 6. Another salient observation, as shown in Table 6, is that the Australians used slightly varied positive semantic carriers in their compliments including Adjectives, Adverbs, and Verbs. Moreover, Verbs were the second positive semantic carriers' preference within the Australians. However, the Indonesians only used Adjectives and Adverbs as positive semantic carriers when they compliment.

\section{Compliment focus}

The results revealed that both Indonesians and Australians gave the major focus of the compliment utterances on the objects/actions of the complimentee. Table 7 below presents the percentage of distribution of compliment by compliment focus.

\section{DISCUSSION}

The results showed that there were some differences as well as similarities between Australian English and Indonesian speakers on paying compliments in terms of compliment types, compliment formula, and compliment focus. 
With regards to the overall distribution of compliment types, Indonesians gave more explicit verbal compliment than the Australian did. One possible explanation for this is that the participants background and the setting of situations in the DCT in this study which involve 'a friend/acquaintance', rather than other types of potential speakers. The factors of power and distance here are of equality and solidarity. It might make the participants feel freer to compliment. In addition, as it mentioned earlier that all the Indonesian participants were university students in various universities in Jakarta, Indonesia, who had learned English for at least six years. They also have great opportunity to expose the western culture through movies and communication as well since people in Jakarta are more diverse and multicultural. As Wolfson (1981, p.118) mentioned that 'a term for complimenting exists in Indonesian, but it usually occurs among the educated who have been exposed to Western customs'.

Further finding on compliment topics revealed that the most frequently preferred topic for the Indonesians and Australians is that of one's ability. This finding is different from the results of the studies of compliments in different varieties of English where these two topics are more or less evenly distributed, with Appearance slightly outranking Performance (Holmes, 1988). On the other hand, the finding on compliment topic in this study is in line with the results of a number of previous studies in how non-native speakers of English paying a compliment (Ye, 1995 in Chinese compliments; Ide, 1998 in Japanese compliments). The results showed that complimenting on ability is more preferred than complimenting on appearance. This suggests that a change in appearance may not be deemed as worthy of complimenting as an ability; new possessions or pretty clothes may not necessarily lead to positive comments in the Indonesians and Australians speech community, whereas an ability is more likely to be complimented. This further indicates that complimenting on ability is more likely to be felt as socially acceptable thus safer - than making compliments on appearance.

In terms of compliment as a gender-preferential strategy, the present study found that $21 \%$ of compliments occurred from males to females in comparison to $14 \%$ from females to males in Indonesian group and $17 \%$ of compliments occurred from males to females in comparison to $15 \%$ from females to males in Australian 
group. This finding appeared consistent with the evidence from previous studies (Holmes, 1988; Parisi \& Wogan, 2006).

\section{Considering}

compliment formulas, the study found that Adjectives were the most frequent positive semantic carriers used by both Australians and Indonesians. However, Australians used Verbs as the second most frequent positive semantic carriers while Indonesians used Adverbs as their second choice. One possible reason for the absence on the use of Verbs in Indonesians is that unlike Australians, Indonesians are not very straightforward in expressing their feelings and opinion as well as their desires. In fact, it is a matter of culture. Australian culture is very direct whereas Indonesian is very indirect. Direct and indirect refer to openness and lack of openness in expressing someone's feelings (Koentjaraningrat, 1993).

In terms of compliment focus, Both Indonesians (79.7\%) and Australians (86.9\%) gave the major focus of the compliment utterances on the objects or actions of the complimentee.

\section{CONCLUSION AND SUGGESTION}

This study investigated the differences and similarities between Australian English and Indonesian speakers on paying compliment in terms of compliment types, compliment formula, and compliment focus. The results in this study revealed that there were more similarities than differences between Australian English and Indonesian speakers on paying compliment with regards to the three categories mentioned before. However, this study only investigates the compliments between interlocutors of equal social status and close relationships. Therefore, its finding will not apply to situations where interlocutors are of unequal social status and distant relationship. Further research on complimenting behaviours among Indonesian and Australian English speakers by using different groups of informants or using different methodology (for instance, natural recordings, to see what people actually say in talking-interaction), to see if the findings of this study still hold.

\section{REFERENCES}

Al Falasi, H. (2007). Just say "Thank You": A study of compliment responses. The Linguistic Journal, 2(1), 28-42. 
Baek, G. (1998). A cross-cultural study of compliments and compliment responses in English and Korean. IRAL, 39(4), 309. Retrieved March 21, 2010, from EBSCOhost database.

Brown, P. \& Levinson, S.C. (1987). Politeness: Some universals in language usage. Cambridge: Cambridge University Press.

Farghal, M. \& Haggan, M. (2006). Compliment behaviour in bilingual Kuwaiti college students. International Journal of Bilingual education \& Bilingualism, 19(1), 94-118.

Hobbs, P. (2003). The medium is the message: Politeness strategies in men's and women's voice mail messages. Journal of Pragmatics, 35(2), 243-262.

Holmes, J. (1988a) Compliment and compliment responses in $\mathrm{New}$ Zealand English. Anthropological Linguistics 28, 485-508.

Holmes, J. (1988b). Paying compliments: a sex preferential positive politeness strategy. Journal of Pragmatics, 12(3), 44546.
Holmes, J. \& Brown, D. F. (1987). Teachers and students learning about compliments. TESOL Quarterly, 21(3).

Holmes, J. (1993). New Zealand women are good to talk to: an analysis of politeness strategies in interaction. Journal of Pragmatics, 20(2), 91-116.

Holmes, J. (2008). An Introduction to sociolinguistics ( $3^{\text {rd }}$ Ed.). London: Longman.

Ide, S. (1998). Sorry for your kindness: Japanese interactional ritual in public discourse. Journal of Pragmatics, 29(5), 509-529.

Koentjaraningrat. (1993). Manusia dan kebudayaan Indonesia. (People and culture of Indonesia). Jakarta: Indonesia : Djambatan

MacKay, A. \& Gass, S.M. (2008). Second language research. Routledge, New York: London.

Manes, J. \& Wolfson, N. (1981) The compliment formula. In Coulmas, F. (Ed.), Conversational Routine (pp.115-132). The Hague: Mouton.

McKay, S. L. \& Hornberger, N. H. (2006). Sociolinguistics and Language Teaching. Cambridge University Press. 
Parisi, C. \& Wogan, P. (2006). Yu, M. C. (2003). On the universality Compliment Topics and Gender. Women and Language 29,21-28. of face: evidence from Chinese compliment response behavior.

Wolfson, N. (1981). Compliments in cross-cultural perspective. TESOL Journal of Pragmatics, 35(10-11), $1679-1710$

Quarterly, 15(2), 117-124.

Ye, L. (1995). Complimenting in Mandarin Chinese . In G. Kasper (Ed.), Pragmatics of Chinese as native and target language (pp. 207-295). Second Language Teaching \& Curriculum Centre, University of Hawaii. 